\title{
Citations in scientific papers
}

\author{
Citações em trabalhos científicos
}

$\mathbf{T}$ The biggest challenge of science is to add something new and practical to knowledge. On the other hand, one of the most common mistakes, responsible for the delay of the same science, is the lack of knowledge of what has been studied and published in literature. In general, in medicine, and particularly in ophthalmology, the technological, medical and surgical advances for the benefit of patients are unquestionable. Early diagnosis of glaucoma and of many retinal diseases has progressed remarkably due to optical coherence tomography (OCT). The number of glaucoma surgeries has been drastically reduced by the use of prostaglandin analogues. The anti-vascular endothelial growth factor (Anti-VEGF) therapy has already benefited many patients. Phacoemulsification associated with the development of increasingly sophisticated and accurate intraocular lens has benefited millions of patients around the world. The modern techniques of keratoplasty allow the recovery of vision in many patients. But surely many eye diseases have no cure yet, requiring the generation of new knowledge. For this to occur, it is necessary for the researchers, the authors of publications and reviewers of journals to be honest and accurate in their work ${ }^{(1)}$. It is also necessary to know that the basic requirements of a scientific paper are originality, reliability, accuracy and consistency ${ }^{(2,3)}$. Unfortunately, it is observed in many studies that the authors, with the irrepressible urge to publish or show off, deliberately omit a review of what has been written before their publication ${ }^{(4)}$. In order to contribute with something new, a careful review of what has already been published must be undertaken. Only thus can the risk be avoided of repeating concepts adequately established in the past as if they were new and original. Moreover, it is well known that the impact factor of a journal, although controversial, is widely used to measure the importance in its area. It is defined by the number of citations of articles published in the journal over the past two years. The higher the impact factor of a journal, the greater its prestige is in the scientific community ${ }^{(5,6)}$. Therefore, the omission of citations of scientific papers of our peers is not tolerated, especially when the papers are authored by the same nationality and often published in the same journal. It causes us wonder that our works are quoted more frequently in journals and chapters in books outside of Brazil. Recently, in the Rev Bras Oftalmol. 2014;73(2):69-70(7) and Rev Bras Oftalmol. 2012;71(3):149-154(8), we were surprised and we regret the lack of citation of one of our papers (Rev Bras Oftalmol. 2004;63(5/6):305-308) ${ }^{(9)}$. We hope that the omission was not intentional and we urge all colleagues to henceforth cite national papers in their publications. This will bring enormous benefit to the papers' integrity and certainly will help to raise the credibility of the journal and its impact. Finally, we quote an excerpt from a preface written in 1964 by Busacca ${ }^{(10)}$ : "Et s'il est vrai qu'en Amérique, très souvent, on ne tient pas compte des observations qui ont déjà vu le jour ailleurs, il est regrettable de constater que cette manière d'agir s'est généralisée et que dans ce monde en bouleversement, l'honnêteté scientifique, jadis très respectée, disparaît peu a peu."

Sebastião Cronemberger Full Professor of Ophthalmology at the Federal University of Minas Gerais, Brazil

\section{REFERENCES}

1. Cronemberger S. A importância do revisor. Rev Bras Oftalmol. 2004;63(7-8):377.

2. Kara-Júnior N. O valor da análise crítica da literatura para a atualização médica continuada. Rev Bras Oftalmol. 2013;72(3):155-6.

3. Kara-Júnior N. Medicina baseada em evidências. Rev Bras Oftalmol. 2014;73(1):5-6.

4. Teixeira RK, Botelho NM, Petroianu A. References from Brazilian medical journals in national publications. Rev Assoc Med Bras. 2013;59(6):571-5.

5. Cals JW, Kotz D. Effective writing and publishing papers, part X: choice of journal. J Clin Epidemiol. 2014;67(3):3.

6. Kara-Júnior N. A democratização do conhecimento médico e seus desafios. Rev Bras Oftalmol. 2013;72(1):5-7.

7. Jorge PA. Opacificação de lente intraocular. Rev Bras Oftalmol. 2014;73(2):69-70.

8. Ventura BV, Ventura M, Lira W, Ventura CV, Santhiago MR, Werner L. Microscopic analysis of opacification in Ioflex® hydrophilic acrylic intraocular lenses. Rev Bras Oftalmol. 2012;71(3):149-54.

9. Cronemberger S, Calixto N, Miranda D, Salles PGO, Maia RS. Estudo clínico e histopatológico de lente intra-ocular opaca explantada. Rev Bras Oftalmol. 2004;63(5-6):304-8.

10. Busacca A. Biomicroscopie et histopathologie de l'oeil. Zurich: Carl Meyer, Jona/Rapperswil SG; 1964. Préface. vol II, p. VI. 